\title{
Inequity in health care utilization in Ecuador: an analysis of current issues and potential solutions
}

\author{
Daniel Lopez-Cevallos ${ }^{1 *}$, Chunhuei Chi $^{2}$ \\ From International Society for Equity in Health: 6th International Conference 2011 \\ Cartegena, Colombia. 26-28 September 2011
}

\section{Background}

From an equity perspective, a health system needs to address social, political and economic inequalities that prevent people to achieve higher standards of living and exert their right to health $[1,2]$. The 2008 Ecuadorian Constitution guarantees the right to health, an important contributing factor to good living or Sumak Kawsay [3]. The purpose of this study was to analyze socioeconomic inequalities and its relationship to provision of health care services in Ecuador, and to discuss relevant policy alternatives.

\section{Methods}

Our analysis on social and economic determinants of health care utilization used the 2004 National Demographic and Maternal \& Child Health Survey (ENDEMAIN) as the main dataset, which included a representative national population sample. To estimate the effects of social and economic variables on health care utilization, we applied two types of analysis, multilevel multivariate analyses by using MLWiN 2.02, and spatial analyses by using GeoDa 0.9.5 [4].

\section{Results}

We found that various layers of social inequalities persist in the Ecuadorian society. Indigenous, low-income, and rural households are particularly limited in their ability to access health care services in Ecuador. Additionally, we explored the influence of migration and remittances in reducing inequalities in health care utilization. We found that having a migrant in the household and receiving remittances improved use of antiparasitic medicines and to a lesser extent curative services, particularly among

\footnotetext{
* Correspondence: lopezced@wou.edu

${ }^{1}$ Community Health, Western Oregon University, Monmouth, Oregon, 97361, USA
}

Full list of author information is available at the end of the article low-income Ecuadorians. Despite the drastic concentration in urban areas of private and public health care providers, we found that density of public practice health personnel is positively associated with use of preventive and curative care, particularly among rural households.

\section{Conclusions}

Our study indicates that major social, economic, and geographic inequalities persist and are associated with access to health care services in Ecuador. Efforts to transform the health care system should go beyond its curative focus to consider an equitable distribution of health care resources and reducing financial and social barriers. These can be best achieved through strengthening government sector public health services, as our study suggest. Further, promoting family and community orientation of services [5,6], and strengthening spaces for public participation and control [7] are also essential to reduce inequalities in access to health care.

\section{Acknowledgments}

This research was supported in part by a Diversity Fellowship from Western Oregon University and a SYLFF Fellowship for International Research. The funders had no involvement in the preparation of this abstract.

\section{Author details}

'Community Health, Western Oregon University, Monmouth, Oregon, 97361, USA. ${ }^{2}$ International Health Program, Oregon State University, Corvallis, Oregon, 97331, USA.

\section{Published: 23 January 2012}

\section{References}

1. Starfield B, Birn A-E: Income redistribution is not enough: income inequality, social welfare programs, and achieving equity in health. Journal of Epidemiology and Community Health 2007, 61(12):1038-1041.

2. Breilh J, Tillería Y: Aceleración global y despojo en el Ecuador: el retroceso del derecho a la salud en la era neoliberal. Quito: Universidad Andina Simón Bolívar - Abya Yala; 2009.

3. Registro Oficial: Constitución política de la república del Ecuador. 2008.

4. Anselin L: GeoDa ${ }^{T M} 0.9$ User's Guide. Urbana, IL: Center for Spatially Integrated Social Science; 2003. 
5. Macinko J, Almeida C, Oliveira EdS, Klingelhoefer de Sá P: Organization and delivery of primary health care services in Petrópolis, Brazil. The International Journal of Health Planning and Management 2004, 19(4):303-317.

6. Starfield B, Shi L: Policy relevant determinants of health: an international perspective. Health Policy 2002, 60(3):201-218.

7. Rodríguez C, Lamothe L, Barten F, Haggerty J: Gobernanza y salud: significado y aplicaciones en América Latina. Revista de Salud Pública 2010, 12(suppl 1):151-159.

doi:10.1186/1475-9276-11-S1-A6

Cite this article as: Lopez-Cevallos and Chi: Inequity in health care utilization in Ecuador: an analysis of current issues and potential solutions. International Journal for Equity in Health 2012 11(Suppl 1):A6.

Submit your next manuscript to BioMed Central and take full advantage of:

- Convenient online submission

- Thorough peer review

- No space constraints or color figure charges

- Immediate publication on acceptance

- Inclusion in PubMed, CAS, Scopus and Google Scholar

- Research which is freely available for redistribution

Submit your manuscript at www.biomedcentral.com/submit 